\title{
АКТУАЛІЗАЦІЯ КАТЕГОРЇ̈ ЧИСЛА ТА РОЛЬ ЧИСЛОВОЇ МОРФОЛОГІЧНОӤ ДОМІНАНТИ В СТРУКТУРІ ТЕКСТУ В РОСІЙСЬКОМОВНІЙ ПОЕЗІЇ НОВОГО ЧАСУ
}

Розглянуто феномен згущення однотипних граматичних форм $i$ значень в межах поетичного тексту або його фрагмента, щзо призводить до формування морфологічної домінанти. Стверджується, що морфологічна домінанта категорії числа значно підвищує експресивність ліричного твору та пов'язана з передачею глибинного поетичного смислу. Схарактеризовано особливості взаємозв'язку морфологічної структури віршового тексту з його композичійно-тематичною структурою. Виокремлено мотиви, щуо актуалізуються згущеенням грамем однини, які формують сингулярну морфологічну домінанту. Описано граматичні значення, що актуалізуються згущенням грамем множини, які спричинюють утворення плюральної домінанти поетичного тексту.

Ключові слова: морфологічна домінанта, сингулярна домінанта, плюральна домінанта, категорія числа, селекція, згущення морфологічної форми, мотив, поетичний текст.

Структура художнього твору є складним утворенням одиниць різних мовних рівнів, які внаслідок тісної взаємодії і складної організації формують певне «ціле, що створене співвідношенням частин, тому перед дослідником постає завдання виявлення цих частин як мовних одиниць, що формують текст» (тут і далі переклад іншомовних джерел наш - H.C.) (Золотова 1996: 284). Композиція ліричного твору підпорядковується дії закону «єдності і щільності» віршового ряду (що був відкритий Ю. Тиняновим), який створює його «третю характерну ознаку - динамізацію мовленнєвого матеріалу» (Тынянов 1965: 67). Динамізація поетичного мовлення проявляється в ущільненості й стислості поетичного тексту, у його більшій інформативній насиченості порівняно з іншими видами художніх творів. У комплексі різнорівневих мовних засобів та їхніх комбінацій, що створюють композиційну структуру ліричного твору, важливими називаємо «власне граматичні засоби, що виконують і композиційно-синтаксичну і виражально-естетичну функцію в тексті» (Золотова 1996: 284). Актуальність вивчення особливостей поетичного функціювання одиниць морфологічного рівня та дослідження експресивних можливостей уживання нормативних форм у віршовому тексті визначається загальною антропоцентричною спрямованістю філологічних досліджень і зумовлюється завданнями сучасної лінгвістики. Морфологічна домінанта, що акумулює однотипні морфологічні форми на обмеженому текстовому просторі й виступає важливою і невід'ємною частиною композиційної структури твору залишається в сучасній лінгвопоетиці та лінгвістиці тексту вивченою фрагментарно. До завдань цієї статті входить з'ясування ролі числової морфологічної домінанти в цілісній структурі поетичного твору, тобто встановлення того, якою $\epsilon$ функційне навантаження згущення морфологічно однотипних одиниць у тексто- і сенсотворенні у зв'язку з актуалізацією граматичних форм та значень категорії числа.

Незважаючи на те, що в більшості текстів граматичний відбір є імпліцитним, він нерозривно пов'язаний із категорією інтенційності, під якою ми розуміємо «зв'язок мовних значень 3 намірами мовця, із комунікативними цілями мовленнєворозумової діяльності, а саме - здатність змісту, вираженого певною мовною одиницею, зокрема граматичною формою (у взаємодії з іiі оточенням, тобто середовищем), бути одним із актуальних елементів мовленнєвого смислу» (Бондарко 2002: 141). Автор свідомо чи підсвідомо здійснює селекцію на всіх мовних рівнях, зокрема й на морфологічному, для реалізації конкретних художніх 
завдань. Усвідомлення цілеспрямованого авторського відбору мовних засобів може бути експліцитно вираженим, наприклад, у назві тексту. Так, у поетичному циклі Бориса Херсонського «Личные местоимения» кожен вірш позначений своєю прономінальною назвою, що обумовлює граматичний відбір. Очевидність авторської селекції домінантних мовних засобів морфологічного рівня у багатьох поетичних творах безсумнівна й помітна читачеві. На нашу думку, вдумливе прочитання поетичного тексту дозволяє виявити не лише домінантні морфологічні форми і значення, але й простежити їхню роль у формуванні й передачі певного поетичного смислу, а також у створенні естетичних ефектів. Досить часто граматична селекція у художніх творах пов'язана з ідеєю числа.

Виразний потенціал категорії числа в поетичному тексті піддавався аналізу в працях І. Іонової, О. Красильникової, Н. Озерової, О. Ревзіної, О. Скоробогатової та інших дослідників. Категорія числа іменника як одна $з$ центральних категорій цієї частини мови, що виражає «кількісні характеристики предметів» (Красильникова 2008: 628), є яскравим граматичним засобом створення поетичної виразності та передачі певних поетичних смислів. У нашій роботі увага буде зосереджена на категорії числа іменників та особових займенників, де число є незалежною морфологічною категорією, на відміну від прикметників, займенниківприкметників, дієслів і дієприкметників, у яких спостерігають синтаксичне узгодження з іменником чи особовим займенником.

Однина у бінарній опозиції числових словоформ виступає як немаркований член $\mathrm{i}$ «має широкий та неоднозначний семантичний діапазон, указуючи не лише на одиничність і кількісну недиференційованість предмета, але й на всю множинність предметів» (Шелякин 2001: 37). Словоформи множини в опозиції числових форм $\epsilon$ маркованими й указують «на той чи той прояв кількісної множинності предметів, самого предмета, сукупностей предметів» або виражають «кількісну невизначеність предметів» (Там само).

Аналіз фактичного матеріалу дозволив виокремити та схарактеризувати віршові тексти, що укладені за принципом цілеспрямованого авторського відбору сингулярних чи плюральних грамем з метою передавання конкретних авторських інтенцій і поетичних смислів.

Розглянемо твори з сингулярною числовою домінантою, під якою ми розуміємо згущення й абсолютне переважання в структурі поетичного тексту грамем однини (у цьому разі представлена суцільна сингулярна домінанта) або відносне кількісне переважання сингулярних грамем на тлі представленості грамем плюральних (у такому випадку перед нами дискретна домінанта).

Сингулярні тексти широко представлені у творчості різних майстрів поетичного мовлення. В одних поетів вони частотні й свідчать про ідіостильові особливості, в інших трапляються рідко або зовсім не трапляються.

Виділені нами ліричні твори із сингулярною домінантою можна поділити на декілька підгруп, виходячи з основного мотиву твору, передачі якого сприяє селекція сингулярних грамем. Російськомовні поетичні тексти нового часу із сингулярною домінантою у багатьох випадках передають мотив самотності й значно впливають на формування певного смислу в цілісній структурі поетичного твору. Тема самотності, що широко представлена в ліричних творах, виражає різноманітність відносин людини й світу. Виступаючи «складною формою пізнання, вираження і комунікації», лірика, на думку І. Ковтунової, «становить глибинне відношення людської діяльності до світу» (Ковтунова 1986: 15). Л. Гінзбург, перелічуючи основні теми лірики, називає тему самотності однією з екзистенційних у тому сенсі, що «вона стосується базових аспектів буття людини» (Гинзбург 1981: 153). Аналізуючи поетико-морфологічні мотиви в мові російської поезії, О. Скоробогатова, виділяє людську і любовну самотність, екзистенційну самотність і под. (Скоробогатова 2012: 408). Цей список не є вичерпним.

Зв'язок мотиву самотності з граматичною селекцією форм однини має витоки у творчості Михайла Лермонтова: «Окремі одночислові вірші трапляються в російській поезії і до Лермонтова. Але саме в цього поета сингулярна селекція і формування у вірші суцільної до- 
мінанти однини починає регулярно поєднуватися з мотивом самотності, перетворюючись на стійкий і відтворюваний поетико-морфологічний мотив» (Скоробогатова 2014: 59-60). Згідно 3 нашими спостереженнями, прийом сингулярної селекції широко використовується для передачі низки мотивів у поезії нового часу.

Головний мотив текстів із сингулярною домінантою, мотив самотності, поділяємо на медитативну i споглядальну самотність, самотність серед людей, любовну самотність, самотність поета (творчу самотність). У текстах із сингулярною домінантою виділяємо також мотив поетичної творчості, мотив туги, мотив розлуки, мотив шляху, мотив спогадів / жалю за минулим та інші мотиви. Розглянемо детальніше граматичну репрезентацію цих мотивів.

Медитативна й споглядальна самотність, які грунтовно описано в роботі Н. Самсоненко (Самсоненко 2017), подаються як феномен «позитивної» самотності внаслідок спроби усамітнення, занурення в себе. Мотив медитативної самотності, що актуалізований грамемами однини, передає стан зосередженості на внутрішньому світі або на зовнішньому фізичному об'єкті з метою переходу до особливого психологічного стану відчуженості. Споглядальна самотність пов'язана зі станом відлюдності та спокою, що необхідні людині для відстороненого сприйняття всього, що відбувається.

Мотив самотності, що актуалізується в поетичному творі грамемами однини, може бути пов'язаний з усвідомленням самотності серед людей, відчуттям протиставлення себе людству чи більшості в історичній епосі.

У вірші Варлама Шаламова «Я жизни маленькая веха...» (Шаламов 2011: 295) відчуття самотності й непотрібності ліричного героя передається як часовими показниками, так і просторовими показниками - конструкцією Метёлка, всаженная в снег. Неможливість говорити правду про те, що відбувається, виражається рядками Я голос, потерявший эхо / В метельный, леденящий век. Безмовний голос ліричного героя протиставляється гучному загальному голосу (С горластым бытом в перепалке). Вірш навіює ідею навколишнього холоду (снег, метельный, ледянящий, мороз), що пов'язана насамперед з реальним холодом у таборах і на засланні, а також із душевною холодністю й байдужістю, що $є$ однією з причин описуваної самотності.

До сингулярних текстів, що виражають мотив самотності серед людей, відносимо також вірш Георгія Іванова «Иду - и думаю о разном...» (Иванов 2011: 173). Суцільна домінанта однини, наявна в цьому тексті, підкреслює основну його ідею - ідею людської самотності у вирі нових історичних подій, яка виражена лексичними засобами: И в этом мире безобразном/ Благообразно одинок. Вірш передає динамічну картину історичних подій, що змінюються (Но сльшиу вдруг: война, идея, / Последний бой, двадцатый век), і становища в ній людини, яка не знаходить собі місця в цьому новому світі: И вспоминаю, холодея, / Что я уже не человек. Ліричний герой відчуває себе «піщинкою» у вихорі історії. Людині зі старими поглядами немає місця в новоствореному світі: А судорога идиота, / Природой созданная зря. / «Урра!» из пасти патриота, / «Долой!» из глотки бунтаря. Усі дієслівні лексеми (иду, думаю, плету, сльши, вспоминаю) є формами 1-ї особи однини теперішнього часу, що, з одного боку, підкреслює окремість зовнішнього світу й ліричного героя $(я-c в i m), 3$ другого, указує на те, що «встановлюється гомохронність ситуації відносно вибраної точки відліку» (Николина 2005: 103). Описувані події подаються очима очевидця, що підкреслено семантикою перцептивного дієслова сльшу.

В ідіостилі Георгія Іванова наявна тема самотності людини, яка перебуває далеко від рідної країни, наприклад, у вірші «Четверть века прошла за границей...» (Иванов 2011: 183). Дискретна сингулярна домінанта сприяє актуалізації мотиву емігрантської самотності: Четверть века прошло за границей, / И надеяться стало смешным. / Лучезарное небо над Ницией / Навсегда стало небом родным. Незважаючи на облаштованість життя і красу чужої країни (Тишина благодатного юга, / Шорох волн, золотое вино), ліричний герой живе надією на повернення до рідного міста. Розділеність простору Ніщца - Петербург у першій і третій строфі підсилюється вживанням різночасових дієслівних форм. У першій строфі при зображенні чужого простору (Ніцца) час передається дієсловами минулого часу: прошло за 
границей, стало смешным, стало родным. У третій строфі простір Петербурга переданий дієслівними формами теперішнього часу: поёт вьюга. Цей факт свідчить про те, що «простір полишеної Росії інколи виявляється для автора більш реальним, ніж ірреальний простір чужого світу (що став або не став рідним)» (Тарасова 2006: 100). Такі часові параметри свідчать про те, що довге життя в чужій країні для ліричного героя вірша $є$ частиною минулого, а життя в рідній країні є надією на майбутнє: пророчество мёртвого друга / Обязательно сбыться должно. Рядки Осипа Мандельштама, що були взяті автором за епіграф, є орієнтиром і поетичною надією.

Любовна самотність у багатьох текстах із сингулярною домінантою має виражений гендерний характер, проте цю особливість не можна назвати універсальною.

Жіноча самотність - досить поширена у любовній ліриці тема. «Жінка завжди переживає самотність тяжче, ніж чоловік. Самотність для неї - та ошкірена реальність, якої вона прагне уникнути. Саме тому тема самотності для жінки завжди щось більш очевидне, ніж для чоловіка» (Хамитов 1995). Самотність жінки, що пов'язана із розставанням та / чи неможливістю бути поруч зі своїм коханим, репрезентована як у поезії авторів-чоловіків, так і у творчості жінок-поеток. Актуалізація мотиву любовної жіночої самотності відбувається через селекцію і згущення грамем однини, що зумовлює формування текстів із суцільною чи дискретною сингулярною домінантою.

Розглянемо вірш Миколи Огарьова «У моря» (Огарёв 1956: 273-274). Морфологічну домінанту передано грамемами однини, на фоні яких функціює одна грамема множини. Перша строфа, де ліричний герой звертається до жінки, яка самовіддано чекає на свого коханого за будь-якої погоди (Дождь и холод! А ты всё сидишь на скале), протиставлена всім іншим строфам, де молода жінка із упевненістю відповідає, чому чекає на свого коханого: $O$ ! я знаю, зачем, я сижу на скале... Грамеми однини передають не лише жіночу самотність і тугу за коханим, але й зосередженість погляду при очікуванні коханого і надію на його повернення: А его различить я сумею во мгле, / Он сегодня вернётся, наверно... Основу часового плану третьої, четвертої та п'ятої строф складає минулий час, що передає спогади про коханого, а саме - момент останньої з ним зустрічі й безпосередньо момент прощання.

Поема Віри Полозкової «Катя» (Полозкова: эл.ресурс) із дискретною сингулярною домінантою сприяє актуалізації теми жіночої самотності. Оповідь побудована як детальний опис невеликого уривка з життя головної героїні твору зі зміною просторових планів, у яких розвиваються основні події: робота (Катя памет неделю между холёных баб) - бар (В пятнииу / вечером Катя приходит в паб и садится на барный стул) - міська вулиця (Город до поролона вспорот, весь жёлт и бел. / Фейерверк с петардами, канонада) - квартира (Катя мечется по квартире, словно над нею заносят кнут) - лікарня (К пяти утра сонный айболит накладывает лангеты, рисует справку и цеенные / указания отдаёт.) - квартира (Мама ходит в лангетах, ревёт над кружкой, которую сложно взять. Был бы / кто-нибудь хоть - домработница или зять.) - морське узбережжя (Катя разглядывает южан, плещется в лазури и синеве, / смотрит на закаты и на огонь). Темпоральна основа оповіді - дієслова теперішнього часу. Швидка зміна подій, що подані в поемі, передає безперервний потік «картин». I саме ця постійна зміна кадрів породжує у вірші динаміку, що здатна наближатися до кінематографічності.

Самотність, яку переживає головна героїня поеми, окрім грамем однини, передана лексично: Вот же время было, теперь, гляди-ка, ты одинока, как Бельй Бим. Одинока / так, что и выпить не с кем, уж ладно поговорить о будущем и былом. / Одинока страшным, обидным, детским - отиовским гневом, пустым углом.

Грамеми множини здебільшого вживаються для передачі набридлого, чужого чи незвичного нового простору для головної героїні: на роботі (Катя памет неделю между холеных баб), у лікарні (Тяжёлого привезли, потасовка в / баре, пять ножевых. Вдоль каждой стенки ещё по паре покоцанных, но жниых. / Ходят медбратья хмурые, из мглы и обратно в мглу. Тряпки, от крови / бурые, скомканные, в углу; Вокруг него санитары / доктора маячат; 
Прибегут, кивнут, убегут опять), на південному узбережжі (Катя разглядывает южсан, плещется в лазури и синеве, / смотрит на закаты и на огонь). Подається група грамем, що передає парні найменування об'єктів (поводит плечами; выскакивает из рук; по куртке пальчиками стуча; челюстями стиснутыми скрипя; когтями не / снабжена; ей лангеты срежут с обеих рук). Звернемо увагу на вживання кількісних числівників у сполученнях, які передають точний опис того, що відбувається: два шота виски по пятьдесят; Катя в /восемь секунд трезва; Скорая в дверь звонит через двадцать и пять минут; Тяжёлого привезли, потасовка в / баре, пять ножевых; Врач говорит - да / чего я сделаю, он же здоровее меня в три раза; К пяти утра сонный айболит накладывает лангеты; Катя лежит с двенадцати до шести. Водночас є приклади приблизної кількості, а саме «два-три, декілька» за допомогою іменника пара: ещё по паре покочанных, но живых; Через пару / недель; через пару часов.

Поема завершується раптовим прозрінням, усвідомленням героїнею того, що вектор іiі долі в іiі руках: Катя просыпается, солние комнату наполняет, она парит, как аэростат. / Катя внезапно знает, что если хочется быть счастливой - пора бы стать. / Катя знает, что в ней и в маме - одна и та же живая нить. То, что она / cтареет, нельзя исправить, но взять, обдумать и извинить. Самотність, що раніше сприймалася як непосильний тягар і вирок, тепер сприймається як тимчасова проблема, яку можна подолати: Катя думает - я, наверное, не одна, я зачем-то ещё нужна. / Там, где было так страшно, вдруг воцаряется совершенная тишина.

Цікавим є приклад, у якому жіноча самотність протиставляється чоловічому життєлюбству. Таке протиставлення знаходимо у вірші Миколи Огарьова «К Лидии» (Огарёв 1956: 245), що має суцільну сингулярну домінанту. Дванадцять рядків вірша можна умовно поділити на дві смислові частини. Перші шість рядків містять опис самотності жінки, яка сумує за минулим, розчарована в майбутньому й тікає від сьогодення, марнуючи день за днем: Когда mbl, грустная, слезу стерев с ресницы, / Задумчиво глядишь на прошлый путь, / Не видишь в будущем ни проблеска зарнищы / И ищешь день убить бы как-нибудь, - / Ведь я сочувствую тебе, и мне обидно / Что жить тебе так страшно тяжело. Приреченість такого існування викликає в поета співчуття і жалість. У структурі ліричного повідомлення на перший план виходить позиція того, хто говорить. І. Ковтунова у зв'язку з цим називає лірику «егоцентричною», але такий «егоцентризм є проявом антропоцентризму людського погляду на світ» (Ковтунова 1986: 18). В аналізованому творі погляд ліричного героя також є суто антропоцентричним. Оповідач відчуває сором за те, що його самотність відрізняється своїм позитивізмом. Слід звернути увагу на те, що початковий рядок вірша Koгда mbl, грустная, слезу стерев с ресницы, на лексичному рівні має очевидний перегук із віршем Михайла Лермонтова «Демон»: И влажный взор её блестит / Из-под завистливой ресницы ..., що вказує на продовження лермонтовської традиції Миколою Огарьовим.

Наступні шість рядків передають світосприйняття ліричного героя, презентуючи його оптимістичну позицію життелюба: А между тем, мой друг, и самому мне стылдно, / Насколько жить мне вольно и светло! / Печален я теперь; но вдруг шипучей влагой / Иль улицы движеньем увлечён, / Я полон становлюсь разгульною отвагой / И в эту жсизнь младенчески влюблен. (Огарёв 1956: 245). У поетичному тексті, що аналізується, протиставлені два типи самотності - негативна, нестерпна, і позитивна, життєстверджувальна. Згідно з нашими спостереженнями, організація морфологічного рівня вірша «працює» на вирішення поетичної задачі реалізації теми самотності. Граматичний аналіз уможливлює вияв морфологічної одноманітності всіх грамем, які мають категорію числа, що свідчить про тісний зв'язок і взаємообумовленість морфологічного рівня та ідейно-образної організації названого ліричного тексту. Граматична селекція сприяє розв'язанню певної поетичної проблеми, передаючи за допомогою використання лише сингулярних грамем конкретні поетичні смисли. Граматичний відбір слугує засобом мовного втілення мотиву самотності, що подається двояко позитивно й негативно. 
Прикладом чоловічої любовної самотності, що передається дискретною сингулярною домінантою, може виступати вірш Арташа Андріасова «А у меня на личном фронте...» (Адриасов 2013: 36). У ліричному творі, окрім грамем однини, самотність героя виражена на лексичному рівні: А у меня на личном фронте / Глухо; Опять никого рядом. Вірш передає гіпертрофоване відчуття самотності, тобто настільки сильне, що кожен звук ззовні ліричний герой сприймає насторожено: Мне кажется каждый скрип / Громом. Для ліричного героя $є$ настільки звичним стан перебування наодинці із собою, що навіть оточення людей посилює його відчуття: Впрочем / Когда их бывает много / Очень / Людей и ещё Бога / Что-то / Становится одиноко. Грамеми однини чергуються 3 грамемами множини в поєднанні 3 невизначено-кількісним словом много: их много, людей. На думку О. Красильникової, відступ у виборі форм числа може бути пов'язаний у тому числі й «з тенденцією до різних аналогій і протиставлень у тексті вірша» (Красильникова 2013: 296). У поданому уривку виділяється протиставлення «один - багато», що актуалізує не лиш чоловічу любовну самотність, але й самотність у суспільстві.

Самотність поета (творча самотність) $є$ одним із важливих мотивів російськомовної поезії нового часу. Творча самотність - це відчуття поетом свого особливого статусу серед інших людей, що часто пов'язане з нерозумінням і відсутністю достатньої кількості однодумців. Ця тема досить яскраво представлена у творчості Олександра Блока. Наприклад: Поэт, тебе ли покарать / Пороки мира вековые? / Один - ты осуждён страдать, / Тебя осмеивать другие! (Блок 1960: 401). «Самотність поета, що вивищується над натовпом» (Скоробогатова 2012: 408), протиставлення поета й натовпу проявляється в приреченості поета мати тяжку долю (Один - ты осуждён страдать), а людського оточення - його осуджувати (Тебя осмеивать-другие).

Розглянемо інший вірш Олександра Блока «Пока спокойною стопою...» (Блок 1960: 32), у якому самотність актуалізується на граматичному рівні дискретною сингулярною домінантою. «Я»-поет протиставлене натовпу, його нерозумінню й неможливості досягти рівня поета: Пока спокойною стопою / Иду, и мыслю, и пою, / Смеюсь над жалкюю толпою / И вздохов ей не отдаю.... Самотність поета сприймається як дар, що виокремлює його 3-посеред інших: И рок велит в себе беречь / И дар незыблемый поэта, / И сцены выспреннюю речь... Творча самотність пов'язана з унікальністю поетичного дару, який апріорі передбачає відокремлене існування. Єдина грамема множини в цьому творі (И вздохов ей не отдаю), що виражає назву дії, підкреслює множинність дій, яку поет не проєктує на кожного з представників натовпу.

Георгій Іванов у вірші «Всё туман. Бреду в тумане я...» (Иванов 2011: 182) відчуває самотність поета як важкий тягар долі, що пов'язаний із приреченістю постійно долати творчий шлях. Його самотність пов'язана з нерозумінням натовпу, незалежно від того, ким є людина 3 натовпу: Всё туман. Бреду в тумане я / Скуки и непонимания. / И-с учёным или неучем-/ Толковать мне, в общем, не о чем. У поета немає вибору, його шлях визначений. Бажання злитися 3 натовпом настільки велике, що він бажає стати пересічною людиною, представником натовпу, який позбавлений індивідуальності, а не поетом: Я бы зажил, зажил заново / He Георгием Ивановым, / А слегка очеловеченным, / Энергичным, щёткой вымытым, / Вовсе роком не отмеченным, / Первым встречным-поперечным - / Всё равно какое имя там... Нерозуміння поета більшістю виражене на граматичному рівні суцільною сингулярною домінантою, що посилює цей мотив самотності.

Дискретна сингулярна домінанта в іншому вірші Георгія Іванова, «Как обидно - чудным даром...» (Иванов 2011: 172), дає змогу єдиній грамемі множини на тлі частотних сингулярних форм виступати засобом передачі особливого поетичного смислу. В аналізованому вірші простежується мотив самотності, що протиставлений зовнішньому світові, але це самотність обдарованої людини, поета: Какобидно-чудным даром, / Божсьим даром обладать, / Зная, что растратишь даром / Золотую благодать. І. Ковтунова зауважує, що «поетична свідомість (ліричне $я$ ) може обмежуватися своїм внутрішнім емоційним світом і навіть бути протиставлена зовнішньому світові, але може й навпаки вміщати в собі широкий зовнішній світ, із яким 
у ліричного поета виникає безпосередній і тісний зв'язок» (Ковтунова 1986: 15). Протиставлення ліричного героя вірша зовнішньому світові, унікальності його дару загалу, який не цінує це, у вірші виражається морфологічно: И не только зря растратишь, / Жемчуг свиньям раздаря, / Но еще к нему доплатишь / Жизнь, погубленную зря... Граматична опозиція домінувальних форм однини, що виражають світ поета (жемчуг, жизнь), і форма множини, яка описує зовнішній антагоністичний світ, набуває поетичної виразності, що актуалізує граматичну внутрішню форму слова, неактуалізовану в звичайному використанні фразеологізму. Ліричний герой вірша не радий своєму дару, він підкреслює, що люди його не поцінують, а скоріше за все, занапастять. Фразеологічна одиниця в другій строфі (жемчуг свиньям раздаря) передає значення марності зусиль поета, неоціненності його дару й приреченості. Сдина в тексті плюральна грамема в шостому рядку (свиньям) актуалізується на фоні сингулярних грамем і передає певний поетичний смисл, ставлячи поета над натовпом.

Низка текстів із сингулярною домінантою пов'язана 3 передачею мотиву поетичної творчості. До цієї групи відносимо тексти, що зображують момент творчого імпульсу й осмислення поетичного таланту.

Сингулярне зображення мотиву поетичної творчості ми зафіксовали в текстах багатьох поетів. Наприклад, в ідіостилі Миколи Глазкова, у віршах «Всё очень просто, хоть и сложно...» (Глазков 1989: 51) і «Слово лучше компаса в пути...» (Глазков 1989: 115) описана цінність поетичного слова як головного життєвого орієнтира (Слово лучше компаса в пути, / Словом можно путь предугадать) (Глазков 1989: 115), а також слово як показник щирості поета (Но не могу писать день каждый, / Ибо не каждый день живу (Глазков 1989: 51); Если слово стало болтовнёй - / Это слово сделалось плохим (Глазков 1989: 51)).

У вірші Миколи Глазкова «Могу ли отделаться лёгким испугом...» (Глазков 1989: 138) ліричний герой шукає відповідь на питання про те, чи має поет право на помилку: Могу ли отделаться лёгким испугом, / Могу ли писателем зваться, / Когда считал человека другом, / А он оказался мерзавцем. Як проста людина, що має іскру божу поетичного дару, ліричний герой розмірковує про справжнє призначення поета, чи здатний він розібратися в усіх тонкощах людської душі: Инженер души или инженер пера, / Очевидно, не знал, что творится, я ... I доходить висновку, що поет-людина, як і Творець, має право на помилку: Ошибался $u$ впредь ошибаться буду. / Даже бог наш среди апостолов / Разглядеть не сумел Иуду. Сингулярна домінанта на граматичному рівні підкреслює осібність поета і його творчості серед загальної людської маси. Вірш виражає пошук призначення поета, пошук життєвого шляху, відповіді на конкретне питання, звідси й граматична однорідність сингулярних грамем, що сприяє актуалізації цього значення.

Iз мотивом самотності, що ми виділяємо як основний мотив, представлений у текстах із сингулярною домінантою, тісно пов'язаний мотив туги. У свідомості більшості носіїв російської мови стан самотності пов'язаний «із почуттями туги, смутку, болю, зі сльозами» (Поздеева 2011: 97). Корпус віршів із сингулярною домінантою, що пов'язаний із мотивом туги, передає самотність як наслідок сильного душевного болю через утрату близької людини чи розставання із нею.

У вірші Олександра Блока «Песня за стеной» (Блок 1960: 442) реалізації поетичного смислу сприяють не тільки лексичні засоби, що виразно називають тему самотності (один, одинокой), але й морфологічні форми, які передають сингулярне значення в поетичному тексті. Поетичний твір розкриває тему самотності, туги ліричного героя за померлою коханою. Дванадцять рядків вірша можна умовно поділити на три фрагменти, що послідовно передають трагізм переживань закоханого. Таке членування підтримується римуванням усередині кожного фрагмента, а також синтаксичною й пунктуаційною організацією (кожні чотири рядки завершуються крапками). У першій частині передано муки ліричного героя, його надії на возз'єднання з коханою: О, наконец! Былой тревоге / Отдаться мыслью и душой! / Вздыхать у милой на пороге / И слушать песню за стеной... У другій частині названо безпосередню тему самотності: Но в этой песне одинокой, / Что звонко плачет за стеной... / Один мучи- 
тельный, глубокий / Тоскливый призрак молодой... Самотнім є привид коханої, самотньою $є$ іiї пісня, самотнім є ліричний герой. У третій частині подаються міркування героя про те, чи можна повірити у факт, що коханої вже немає: $O$, кто ужасному поверит / И кто усльшит стон живой, / Когда душа внимает, верит, - / А песня смолкла за стеной!.. Ліричному героєві хочеться бути почутим, але його стогін ніхто не чує, він самотній.

Граматичний аналіз засвідчує, що текст організований сингулярними грамемами. Морфологічна домінанта $є$ суцільною. Одиниці морфологічного рівня у вірші взаємодіють із одиницями лексичного рівня (лексемами із семантикою самотності). Академік В. Виноградов зазначає, що «у стилі письменника відповідно до його художніх замислів, об'єднаними, внутрішньо пов'язаними й естетично виправданими є всі мовні засоби, що використані митцем» (Виноградов 1959: 169). У представленому вірші мовні одиниці лексичного й морфологічного рівнів, доповнюючи та підсилюючи одна одну, максимізують естетичний ефект, розширюють свої семантичні й експресивні можливості, поглиблюючи поетичний смисл твору.

Мотив туги як відчуття непоправної душевної пустоти внаслідок утрати близької людини знаходимо у творчості Андрія Дементьєва:

\section{Душа моя- \\ Как тонущая лодка. \\ Вычерпьваю боль, \\ А боль не убывает.}

Наверное, со всеми так бывает,

Когда в судьбу нежданно

Входит смерть.

(А. Дементьєв. «Памяти сына») (Дементьев 2010: 281).

Душевний стан ліричного героя в цьому творі порівнюється 3 посудиною, що постійно наповнюється невичерпним болем. Туга за померлим сином порівнюється 3 почуттями всіх батьків, які зазнали подібної втрати: Наверное, со всеми так бывает, / Когда в судьбу нежданно / Входит смерть.

Вірш Андрія Дементьєва «Евгению Мартынову», присвячений пам’яті відомого співака і композитора, із дискретною сингулярною домінантою передає тугу за близькою людиною, яка пішла $з$ життя. Ліричний герой, звертаючись до померлого друга, намагається прийняти його смерть як перехід із земного світу в інший світ: Кому Господь благоволит, / Того Он забирает рано... (Дементьев 2010: 296). А в певному сенсі - як порятунок і перехід у більш духовний світ: А ныне, словно на таран, / Несётся пошлость по экранам, / Вряд ли светлый твой талант / Вписался б в этот хор бездарный. Фізична смерть подається як така, що не може знищити пам'ять про людину: И вновь я верю-смерти нет, / Когда звучит твой чудный голос... (Дементьев 2010: 297).

Туга як почуття, що стискає, подане у вірші Владислава Ходасевича «Вокруг меня кольцо сжимается...» (Ходасевич 2003: 47). У тексті мотив самотності виражений на лексичному рівні, а граматична будова його підсилює. Туга описується у вигляді почуття, що поглинає, i якому ліричний герой не в змозі протистояти: Вокруг чела Тоска сплетается / Моей короной роковой. Мотив туги поєднується з іншими негативними почуттями, що передано прислівниками печально й зауньвно. Семантика кола, подана в цьому вірші й реалізована в повторюваних лексемах кольцо й вокруг, а також в іменниках труба й корона, має глибокий підтекст. По-перше, круг і кольцо, що мають багатошарову семантику в образно-міфологічній свідомості можуть означати долю, що зберіглася й дотепер у вигляді зображення римської богині Фортуни, яка стоїть на кулі чи колесі. У вірші це передається за допомогою образу рокової корони. По-друге, слово круг набуває певної негативної оцінної конотації через суголосність зі словом кручина, тобто «те, що знесилює моральну людину: смуток, туга, печаль, засмучення, горе, тривале душевне страждання, знемога» (Даль 2006: 116). I найголовніше, прислівник вокруг, що тричі повторюється, описує «простір відносно суб'єкта, серединне положення якого при використанні прислівника передбачається автоматично» (Тильман 
2000: 444). Цей круговий замкнутий простір передає відчуття лещат, що стискають людину: Вокруг меня кольио сжимается. Простір зменшується, стискається до меж голови, що символізує зосередженість розумово-ментального центру: Вокруг чела Тоска сплетается. / Моей короной роковой. Дієслово сплетается недоконаного виду передає значення поступового проникнення.

Поетичні тексти із сингулярною домінантою сприяють актуалізації мотиву розлуки, розставання, роз'єднання, відокремленості. Мотив розлуки тісно пов'язаний 3 мотивом самотності. Самотність, що $є$ наслідком розлуки, певною мірою представлена в цій групі текстів. Але мотив розлуки, роз'єднаності є основним у них.

В одному з віршів із сингулярною домінантою Миколи Огарьова «Разлука» мотив розлуки переданий від імені жінки, яка очікує на повернення свого коханого з чужини: Жив ли милый мой? / Что-то он не пишет / С стороны чужой! (Огарёв 1956: 267). Погляд ліричної героїні, яка проводить безсонну ніч у роздумах про дорогу серцю людину, спрямований у вікно, що є символом поділу простору на свій (той, що в домі) і чужий, віддалений (той, що знаходиться за вікном). Як у першій, так і у другій строфі відбувається переміщення з дальнього плану на ближній: луна / солнще - ива - лист ивыл. Притаманна Огарьову полярність сприйняття світу проявляється в цьому творі. Зміна часу доби, ночі й ранку, і наступна зміна світлових барв (Ночь была прозрачна: / Мирный блеск луны, / Синей мглы мерцанье, / Кротость тишины...; Утро проглянуло / Золотым лучом, / Мне в окно пахнуло / Ранним ветерком) призводить до зміни настрою і стану ліричної героїні від безнадійного (Что-то он не пишет / C стороны чужой!) до такого, що вселяє надію на повернення (Скоро ли напишет / C стороны чужой?). Ніч і ранок, як протиставлення темної і світлої частини доби, пов'язані 3 універсальною опозицією «жіноче - чоловіче». Це протиставлення «має послідовне граматичне відображення в російській ліриці» (Ф. Тютчев «День и ночь», О. Блок «Золотокудрый ангел дня») (Скоробогатова 2015: 295). Зміні настрою сприяє й те, що в першій і другій строфі по-різному представлений стан верби, що росте за вікном, від статично-нерухомого (Нашей старой ивы / Не качался лист / И висел безмолвно - / Свеж и серебрист) до динамічного, рухомого вітром (Нашей старой ивы / Встрепенулся лист / Шорохом дрожащим - / Зелен и росист). Образ старої верби (uвы) є символічним, у ньому є видимими окремі риси прообразу світового дерева. Верба в російськомовній поезії часто пов'язана 3 мотивом розлуки. Стара верба в цьому вірші виконує роль «каталізатора» того, що відбувається в чужій країні. Зміна стану листя дерева від статичного до динамічного виступає як «символ пам'яті про минуле і надії на майбутнє» (Эпштейн 2007: 41). Образ верби в цьому контексті асоціюється 3 образом жінки, яка страждає, оскільки верба в російській поетичній традиції має сталий епітет плакучая.

Мотив розлуки яскраво переданий в одному з віршів Марлени Рахліної, присвяченому другові-поету Борису Чичибабіну, «Благодарность» (Рахлина 1996: 90). Твір побудований за принципом розділеності простору Я/Ти: Я от тебя, ты от меня - далеко. Духовному єднанню двох близьких людей перешкоджає розподіл світу на два віддалених простори: простір «тут», тобто простір ліричної героїні, і далекий простір, «твій простір»: Друг друга зная, помня и любя, / мы врозь идём. Ииу свою дорогу / не так, как ты, - отдельно от тебя. Поділ простору актуалізується прислівниками врозь і отдельно. У цьому вірші формула $Я / T b l=M b l$ можлива лише за умови паралельного співіснування. Відчуття близькості на відстані передається зображенням схожого напряму життєвого руху у двох різних просторах: Ho mbl идёшь - и значит, я не слягу, / но ты идёшь - и легче мне идти.

Подолання почуття, що поглинає, яке виникає внаслідок розлуки репрезентовано у вірші Арташа Андріасова «...И под сумрак дождя...» (Адриасов 2013: 46). Перші рядки твору містять опис відчуття душевної пустоти й фізичної слабкості ліричного героя: ...И под сумрак дождя я согнусь под зонтом, как иветок / без водь, наклонённый вперёд.... Розлука зображується як певна точка відліку часу для ліричного героя, після якої момент прощання поглинає його думки: Оставаться стоять на перроне прохладном, там, где / поезд ушедший тобою 
загадан. Для ліричного героя важливим є момент подолання розлуки, «трансформації» почуттів у віршову форму як момент звільнення від тяжких емоцій: Рандеву перед зеркалом в несколько / слов: "Дай мне силь пройти от любви до стихов!». Розлука, розділеність, окрім актуалізації на морфологічному рівні дискретною сингулярною домінантою, на фонетичному рівні посилюється алітерацією, повторенням р: сумрак; вперёд; на перроне прохладном; над каждой строкой, как судьбой Ахиллеса короткой, / трепещу, изнутри покрываясь росой первой страсти; Рандеву перед зеркалом; пройти.

Поетичні тексти із сингулярною домінантою часто пов'язані з досить частотним у російськомовній поезії мотивом шляху і його подолання. Путь як багатозначне слово, контактно взаємодіючи в поетичному контексті з іншими лексичними компонентами, передає безліч смислів і передусім рух, але найчастіше ця лексема пов'язана 3 пошуком конкретного життєвого смислу, напряму, у якому треба рухатися, із пошуком життєвого призначення. Після вірша Михайла Лермонтова «Выхожу один я на дорогу...», що є твором із дискретною сингулярною домінантою і передає мотив самотності, спостерігаємо реалізацію мотиву шляху і в інших ідіостилях як продовження лермонтовської традиції.

У творчості Миколи Огарьова мотив шляху сприяє опису бажання ліричного героя піти в далеку невідому сторону: Что мне в сей жизни скучной? / Я лучше же уйду... (Огарёв 1956: 137). Кращий світ, якого так прагне ліричний герой, не має конкретного опису чи назви, а також не має і конкретної траєкторії, дороги. Рух ліричного героя визначається траєкторією уявного руху по сцені, що сприймається. Перенесення в інший простір порівнюється зі швидким рухом на коні, який є поетичним символом стрімкого руху: У лошади подручной / Взяв тонкую узду. / Не хуже подседельной / Она меня домчит. Новий простір сприймається ліричним героєм як чарівний i казковий, із прекрасною дівчиною, яка готова стати для нього незмінною супутницею: Где дева - coeli lumen - /Невинностью дыша, / Точь-в-точь святой игумен, / Не любит антраша; / Бежит от шума света, / Одну любовь любя... Образ чарівної супутниці подається як образ дівчини, яка знає точний орієнтир, шлях до нового простору: И путь укажет чуда / В безвестный край чудес.

Образ стрімкого руху життєвим шляхом спостерігаємо і в іншому вірші Миколи Огарьова «К друзьям» (Огарёв 1956: 60-61). Життєвий шлях представлений лексемою дорога, що реалізує «конкретно-просторове значення» (Яковлева 2005: 268), на відміну від лексеми путь, що актуалізує «певний функційно-смисловий зміст і тому <..> не має конкретно-просторової локалізації» (Там само). Лексема дорога наповнена конкретним смислом, у ній закладений об'єм подій, що відбувалися / відбуваються в житті ліричного героя: Я по дороге жизни этой / Скачуна чёрном скакуне. Вірш має чіткий просторово-часовий поділ, у якому образ коня знову $\epsilon$ символом переходу до іншого простору. Перша строфа пов'язана з чужим і незвіданим простором (Со мною рядом что за лища? / Куда бегут? Зачем со мной? / Скучна их пёстрая станица, / Несносен говор их пустой), досягти якого прагне ліричний герой зі своєю коханою. Часовий план цієї строфи - план сьогодення і безпосередньо пов'язаного з ним майбутнього: Куда нас мчит бегун суровый? / Где остановит он свой бег? / И где приют для нас готовый? / Нам в радость будет ли ночлег? Друга та третя строфи пов'язані із часовою площиною минулого, що виражається спогадами ліричного героя. У просторовому аспекті це минуле розповідає про рідну країну, із якою пов'язані найтепліші спогади: Когда ж, случится, взор устальй / Назад бросаю я порой, / Я вижу радости бывалой / Страну далёко за собой. Рідна країна, пов'язана зі спогадами про юність і друзів, описана, окрім лексичних засобів (Но ту страну, душе родную), багаторазовим повторенням займенникового прислівника там: Там ясно утро молодое, / Там веет свежею весной, / Там берег взброшен над рекою / И шумен город за рекой, < ..> // Там пел я вольность удалую, / Там были вместе мы, друзья, / Там верил я в удел высокий, / Там было мне осьмнадиать лет. Займенниковий прислівник там, який установлює «позицію мовця у просторі й часі» (Ковтунова 1986: 47), указує не на конкретний простір, що постає перед очима ліричного героя, а на далекий простір «недоступний для зорового сприйняття» (Ковтунова 1986: 51). Реалізації просторового поділу «чуже - рідне» 
сприяють також указівні займенники эта й та: Я по дороге жизни этой / Скачу на чёрном скакуне; Но ту страну, душе родную, / Уже давно оставил я. Часовий поділ на «теперішнє минуле» підтримується дієслівними лексемами теперішнього (скачу) і минулого часу (оставил). Часовий план теперішнього актуалізується вказівним займенником эта, що «встановлює центр сприйняття, позицію мовця» (Ковтунова 1986: 36), а часовий план минулого часу актуалізується займенником та, який указує на «предмети і явища, що є в уяві та пам'яті» (Ковтунова 1986: 42). Окрім цього, на два розділені просторово-часові пласти вказують присвійні та особові займенники: чужий і близький простір я - они (Скучна их пёстрая станица, / Несносен говор их пустой), свій, проте далекий простір я-мы (Там были вместе мы, друзья).

Мотив дороги, символізуючи життєвий шлях однієї людини чи декількох людей, у поетичному творі може тісно переплітатися з мотивом розлуки. У вірші Владислава Ходасевича «Кольца» (Ходасевич 2003: 66-67) спільний життєвий шлях ліричного героя і його супутниці переривається, на них чекає розлука внаслідок того, що вони йдуть різними шляхами: Tы уходишь в ночную дорогу, / Не боясь, не дрожа, не смотря. / Ты доверилась тёмному богу? / Не возьмёшь моего фонаря?

У поетичних текстах із сингулярною домінантою у деяких випадках актуалізований мотив спогадів чи жалкування. Такі тексти часто пов’язані з часовим планом минулого.

Вірш Миколи Глазкова «Жизнь во многом была дрянна...» із дискретною сингулярною домінантою передає плин життя як шлях із чергою помилок і невдач, що залишилися в минулому: Жизнь во многом была дрянна, / Но минувшее не возвратить... (Глазков 1989: 116). Життєвий шлях ліричний герой сприймає вже не як те, що хотілося б змінити, а як багатий досвід, що надає сили для нових звершень: Нету в мире такого бревна, / Чтобы я не мог своротить; Разве книга такая есть, / Чтобы я не смог сочинить? Єдиний іменник множини друзья в останній строфі створює контраст із першою і другою строфами. Ліричний герой розраховує не лише на власні сили, але й на підтримку друзів: Нету в мире такого врага, / Чтоб друзья не могли победить.

Згадки про цілий життєвий шлях людини можуть конкретизуватися грамемами однини за повної відсутності грамем множини. Спостерігаємо це явище у вірші Марлени Рахліної «Дочери» (Рахлина 2006: 55). Життєва дорога доньки зображується ліричною героїнею як спогади про чергу часових планів, що змінюються і знаменують собою певний життсвий етап: Всё-то я помню, любимая дочка: / время, когда ты была словно почка, / время, когда ты в цветок / нежный и трепетный вмиг превратилась, / прелестью девичьей тихо укрылась / и заневестилась, спелая вишня, / и -мне для радости -замужс ты вышла... / Далее, далее тёк / ток твоей жизни - и сын твой родился (Там само). Невблаганний плин часу передається повторенням предикативної одиниці вертится шарик земной. Грамеми однини сприяють передачі зображення певної картини, створюючи разом динамічну хронологічну картину: дитинство - підлітковий вік - юнацтво - заміжжя - народження дитини.

Окрім описаних мотивів, що актуалізуються сингулярною домінантою, виділяємо також корпус російськомовних поетичних текстів нового часу з іншими мотивами. Ці мотиви ми зафіксували як часткові, нетипові випадки. 3 одного боку, це не виключає можливості повторення того чи того мотиву в інших текстах, з другого, ми виділяємо конкретний мотив як характерний для певного тексту чи ідіостилю. Ця група текстів характеризується тим, що сингулярна домінанта, утворена грамемами однини, актуалізує в текстах значення унікальності й конкретності.

Сингулярна домінанта окремого поетичного тексту може брати участь в актуалізації й таких мотивів:

- вираження відчуття потреби в супутникові життя на противагу самотності (А. Андріасов «Один человек» (Адриасов 2013: 16-17));

- незмінності життєвих засад і циклічності життя (Ю. Кузнецов «Стояние» (Кузнецов 2011: 257)); 
- екзистенційної самотності, а саме - відчуття неминучості смерті, кінця, певного життєвого сценарію (Б. Кенжеєв «... и даже этот чёрный вечер...» (Кенжеев 1995: 132), Ю. Кузнецов «Ой ты, горе, луковое горе...» (Кузнецов 2011: 255));

- відмирання, в’янення (В. Шаламов «А тополь так высок...» (Шаламов 2011: 331));

- відданості й однолюбства (М. Огарьов «Она никогда его не любила...» (Огарёв 1956: 152)), що пов'язаний з мотивом любовної самотності. Поданий список відкритий і може бути доповнений.

Розглянемо плюральну числову домінанту, під якою розуміємо згущення й абсолютне превалювання в структурі поетичного тексту грамем множини (у цьому випадку представлена суцільна плюральна домінанта), або значне кількісне переважання плюральних грамем на тлі представленості грамем сингулярних (у такому разі перед нами дискретна домінанта). Поетичні тексти 3 плюральною числовою домінантою кількістю поступаються текстам із сингулярною домінантою, але є високо експресивними.

Плюральні тексти із суцільною числовою домінантою - явище досить рідкісне, радше нетипове, представлене нечисленними зразками. Поетичний текст із суцільною плюральною домінантою знаходимо в Олександра Блока «И нам недолго любоваться...»:

И нам недолго любоваться

На эти, здешние, пиры:

Пред нами тайны обнажатся,

Возблешут дальные миры.

(А. Блок. «И нам недолго любоваться...») (Блок 1960: 162).

Ліричний герой вірша розглядає себе як частину великого зовнішнього світу, що передається суцільною плюральною домінантою. Герой тут уже не самотній, він сповнений рішучості переходу в інші світи разом із іншими. Хоча ліричний твір позбавлений надриву, семантика трагізму й приреченості в ньому наявна. У чотирьох рядках поетичного тексту знаходимо грамеми множини, що пов'язані зі значенням приреченості всього сущого та неминучості переходу в інший світ. Так, плюральні грамеми в аналізованому вірші створюють певний естетичний ефект.

Тексти із дискретною плюральною домінантою складають кількісно більшу групу. У деяких текстах із плюральною домінантою грамеми множини, «що вживаються в узагальнювальному значенні, називають клас, тип людей» (Красильникова 2013: 299). Як, наприклад, у вірші Георгія Іванова «Воскресают мертвецы...» (Иванов 2011: 118). Антиномія життя і смерті показана автором як «воскресіння» мертвих (Воскресают мертвецы, / Наши деды и отцы, / Пращуры и предки) і помирання живих (Вымирают города, / Мужнки и господа, / Старички и детки). Конкретність світу мертвих і світу живих передана грамемами однини: Рвутся к жизни, как птенцы, / Из постылой клетки. Відсторонений погляд на світ двох співнаявних реальностей подано в останній строфі: И глядит на мир звезда / Сквозь сухие ветки. Переважання форм множини у вірші і єдина сингулярна грамема в останній строфі сприяє створенню зображення конкретної точки споглядання (И глядит на мир звезда) подій, що відбуваються в окресленому просторово-часовому континуумі.

У вірші Варлама Шаламова «Мои дворцы хрустальные...» (Шаламов 2011: 234-235) плюральні грамеми в складі рядів однорідних членів також сприяють передачі ідеї великого простору, що оточує ліричного героя: Мои дворцы хрустальные, / Мои дороги дальние, / Лиловые снега...; Безлюдные, холодные, / Урочища бесплодные, / Безвыходные льды... За словами О. Красильникової, «у рядах однорідних членів у поезії діє загальна тенденція до вирівнювання числових форм» (Красильникова 2005: 194). Закритість простору (двориы) змінюється розширенням відкритого простору (дороги, снега, урочища, льды). Форма множини в цьому разі «передає значення широкої просторової протяжності» (Ревзина 1988: 66-67). Плюральними грамемами передаються творчі потенції ліричного героя (Мои побаски вольные, / Мои стихи крамольные), а також табірний світ в'язнів і наглядачів довкола нього (Больные, бестолковые / С лопатами совковыми / Шеренгами встают ... // Рядясь в плащи 
немаркие, / С немецкими овчарками / Гуляют пастухи). Порівняння однієї лексеми у формі однини і множини (Не поиск нужен истины, / A поиски еды) актуалізує значення втрати морального орієнтира через суворі умови життя: Молиться Богу истово / Безбожники идут. Переважання плотського над духовним у жорстокому табірному світі посилює песимістичний настрій ліричного героя: Кружится заметь вьюжная, / И кажутся ненужными / Стихи... Сувора правда колимської реальності Варлама Шаламова викриває сутність кожної окремої людини і маси схожих людей.

Вірші як мозаїка життєвих моментів, як кожний окремий спогад на життєвому шляху подано у вірші Миколи Некрасова «Стихи мои! Свидетели живые...»:

Стихи мои! Свидетели жсивые

За мир пролитых слёз!

Родитесь вы в минуты роковые

Душевных гроз

И бъётесь о сердца людские,

Как волны об утёс.

(М. Некрасов. «Стихи мои! Свидетели живые...») (Некрасов 1985: 100)

Форми множини, з одного боку, актуалізують значення точковості, унікальності кожного пережитого поетом моменту і згодом викладеного в кожному окремому поетичному творі, 3 іншого боку, передають сукупність цих віршів як цілісної індивідуально-авторської поезії.

У вірші Віри Павлової «Не овец, с холмов гонимых...» представлена дискретна плюральна домінанта, де грамеми множини вказують на певні сукупності, що складають множинності з однорідними чи схожими ознаками:

Не овец, с холмов гонимых,

не фарфоровых слонов, -

пересчитывай любимых,

постояльцев прежних снов,

прежде сна лишавших, бывиих

всем, качавших на руках...

Пересчитывай любимых.

Ик утру заснёшь в слезах.

(В. Павлова. «Не овец, с холмов гонимых...») (Павлова 2007: 70)

Перші чотири рядки виражають звертання з конкретним закликом до того, що потрібно чи не потрібно робити: Не овеи, с холмов гонимых, / не фарфоровых слонов, - / пересчитывай любимыхx, / постояльцев прежних снов.... Множина в зазначеному уривку «пов'язана із індікативом, із указівкою на те, що позначається не просто клас предметів і явищ, які складають однорідну множину, а тих, що реально мали місце й набули матеріальної реалізації, диференційованих, невичерпно різноманітних об'єктів, які формують цю множину» (Ревзина 1989: 213). Протиставлені форми множини іменника снов та однини сну передають значення протиставленості снів-подій сну-стану.

Проведене дослідження дозволило виокремити й описати особливості взаємозв'язку морфологічної структури ліричного твору з його композиційно-тематичною структурою. Авторська селекція за певною морфологічною ознакою i, як результат іiі прояву, згущення однотипних граматичних форм і значень у поетичному творі чи його фрагменті призводять до формування морфологічної домінанти. Наявність морфологічної домінанти значно підвищує експресивність поетичного тексту та, як правило, пов'язана з формуванням і передачею певного поетичного смислу.

Актуалізація форм і значень категорії числа, що має високий ступінь семантизації, зумовлює високу поетичну виразність цієї категорії в складі морфологічної домінанти поетичного тексту. Згущення грамем однини в ліричному творі призводить до утворення сингулярної домінанти. Такий тип домінанти відносимо до фонової домінанти. Сингулярні домінанти передають значення самотності і на граматичному рівні актуалізують це значення 
у віршовому тексті. Сингулярне подання мотиву самотності має різні варіанти реалізації, але авторська граматична селекція, свідома чи підсвідома, є одним із засобів актуалізації поетичного смислу. Головний мотив текстів із сингулярною домінантою, мотив самотності, поділяємо на медитативну й споглядальну самотність, самотність серед людей, любовну самотність, самотність поета (творчу самотність), мотив поетичної творчості, мотив туги, розлуки, мотив шляху, мотив спогадів / жалю за минулим, мотив вираження відчуття необхідності супутника життя на противагу самотності, мотив незмінності життєвих засад, а саме відчуття неминучості смерті, кінця, певного життєвого сценарію, мотив відмирання, в'янення, мотив відданості й однолюбства. Список мотивів, що актуалізуються згущенням грамем однини і формують сингулярну морфологічну домінанту, відкритий.

Згущення грамем множини спричинює утворення плюральної домінанти, яку ми відносимо до актуалізованого типу домінанти. У поетичному тексті плюральна домінанта сприяє актуалізації значення множинної одноманітності, безперервності, циклічності процесів, що відбуваються, циклічності розвитку процесів для виділення значення унікальності й одиничності події або явища, що описується, при використанні одиничних сингулярних грамем на тлі плюральних. Плюральна морфологічна домінанта також може актуалізувати значення простору та його протяжності.

Морфологічні одиниці й категорії в складі морфологічної домінанти набувають особливостей поетичного функціювання, підпорядковуючись законам загальнонаціональної мови і мови поезії. Актуалізація сталих у мові граматичних значень і формування контекстуальних значень морфологічних одиниць у віршовому тексті створює виразні художні ефекти, стає основою формування та передачі особливих поетичних мотивів і смислів, збільшує багатозначність ліричного твору.

Дослідження відкриває перспективи подальшого всебічного вивчення різних типів морфологічних домінант поетичного тексту та їхньої ролі у структурі ліричного твору.

\section{Література}

Бондарко, Александр В. Теория значения в системе функциональной грамматики: На материале русского языка. Москва: Языки славянской культуры, 2002.

[Bondarko, Aleksandr V. Teoriya znacheniya v sisteme funkcional'noj grammatiki: Na materiale russkogo yazyka. Moskva: Yazyki slavyanskoj kul'tury, 2002.]

Виноградов, Владимир В. О языке художественной литературы. Москва: «Гослитиздат», 1959.

[Vinogradov, Vladimir V. O yazyke hudozhestvennoj literatury. Moskva: «Goslitizdat», 1959.]

Гинзбург, Лидия Я. «Частное и общее в лирическом стихотворении». Bonpocbl литературы 10, 1981: 152-175.

[Ginzburg, Lidiya Ya. «Chastnoe i obshchee v liricheskom stihotvorenii». Voprosy literatury 10, 1981: 152-175.]

Даль, Владимир И. Большой иллюстрированный словарь русского языка: современное написание: ок. 1500 ил. Москва: Астрель: АСТ: Транзиткнига, 2006.

[Dal', Vladimir I. Bol'shoj illyustrirovannyj slovar' russkogo yazyka: sovremennoe napisanie: ok. 1500 il. Moskva: Astrel': AST: Tranzitkniga, 2006.]

Золотова, Галина А. «Композиция и грамматика». [В:] 3.Ю. Петрова, Н.А. Фатеева (ред.кол.) Язык как творчество. Сб. статей к 70-летию В. П. Григорьева. Москва: ИРЯ РАН, 1996, 284-296.

[Zolotova, Galina A. «Kompoziciya i grammatika». [V:] Z. Yu. Petrova, H.A. Fateeva (red.kol.) Yazyk kak tvorchestvo. Sb. statej k 70 letiyu V.P. Grigor'eva. Moskva: IRYA RAN, 1996, 284-296.]

Ионова, Ирина А. Морфология поэтической речи. Кишинев: Штиинца, 1988.

[Ionova, Irina A. Morfologiya poeticheskoj rechi. Kishinev: Shtiinca, 1988.]

Ковтунова, Ирина И. Поэтический синтаксис. Москва: Наука, 1986.

[Kovtunova, Irina I. Poeticheskij sintaksis. Moskva: Nauka, 1986.] 
Красильникова, Елена В. «Категория числа имен существительных». [В:] И. И. Ковтунова, Н. А. Николина, Е. В. Красильникова (отв. ред.) и др. Поэтическая грамматика. Москва: ООО Издательский центр «Азбуковник», 2005. Том I, 188-236.

[Krasil'nikova, Elena V. «Kategoriya chisla imen sushchestvitel'nyh». [V:] I.I Kovtunova, N.A. Nikolina, E.V. Krasil'nikova (otv. red.) i dr. Poeticheskaya grammatika. Moskva: OOO Izdatel'skij centr «Azbukovnik», 2005. Tom I, 188-236.]

Красильникова, Елена В. «Композиционные формы употребления форм числа существительных в стихотворениях В. Хлебникова и Н. Заболоцкого». [В:] Е. В. Красильникова (отв.ред.) и др. Поэтическая грамматика. Москва: ООО Издательский центр «Азбуковник», 2013. Том II, 287-308.

[Krasil'nikova, Elena V. «Kompozicionnye formy upotrebleniya form chisla sushchestvitel'nyh v stihotvoreniyah V. Hlebnikova i N. Zabolockogo». [V:] E.V. Krasil'nikova (otv.red.) i dr. Poeticheskaya grammatika. Moskva: OOO Izdatel'skij centr «Azbukovnik», 2013. Tom II, 287-308.]

Красильникова, Елена В. «Число». [В:] Ю. Н. Караулов (ред.) Русский язык: энциклопедия. Москва: Научное издательство «Большая Российская энциклопедия», Дрофа, 2008, 628-629.

[Krasil'nikova, Elena V. «Chislo». [V:] Yu. N. Karaulov (red.) Russkij yazyk: enciklopediya. Moskva: Nauchnoe izdatel'stvo «Bol'shaya Rossijskaya enciklopediya», Drofa, 2008, 628-629.]

Николина, Наталья А. «Категория времени глагола». [В:] И. И. Ковтунова, Н. А. Николина, Е. В. Красильникова (отв. ред.) и др. Поэтическая грамматика. Москва: ООО Издательский центр «Азбуковник», 2005. Том I, 73-187.

[Nikolina, Natal'ya A. «Kategoriya vremeni glagola». [V:] I.I. Kovtunova, N.A. Nikolina, E.V. Krasil'nikova (otv. red.) i dr. Poeticheskaya grammatika. Moskva: OOO Izdatel'skij centr «Azbukovnik», 2005. Tom I, 73 -187.]

Поздеева, Нина С. «Место концепта «Одиночество» в русской языковой картине мира». Вестник Северного (Арктического) федерального университета 2, 2011: 95-98.

[Pozdeeva, Nina S. «Mesto koncepta «Odinochestvo» v russkoj yazykovoj kartine mira». Vestnik Severnogo (Arkticheskogo) federal'nogo universiteta 2, 2011: 95-98.]

Ревзина, Ольга Г. «Выразительные средства поэтического языка М. Цветаевой и их представление в индивидуально-авторском словаре». [В:] В. П. Григорьев (отв.ред.) Язык русской поэзии XX века (сборник научных трудов. Москва: Институт русского языка АН СССР, 1989, $195-222$.

[Revzina, Ol'ga G. «Vyrazitel'nye sredstva poeticheskogo yazyka M. Cvetaevoj i ih predstavlenie v individual'no-avtorskom slovare». [V:] V.P. Grigor'ev (otv.red.) Yazyk russkoj poezii XX veka (sbornik nauchnyh trudov. Moskva: Institut russkogo yazyka AN SSSR, 1989, 195-222.]

Ревзина, Ольга Г. «Категория числа в поэтическом тексте». [В:] О. Г. Ревзина (ред.) Актуальные проблемы русской морфологии. Москва: МГУ, 1988, 66-79.

[Revzina, Ol'ga G. «Kategoriya chisla v poeticheskom tekste». [V:] O.G. Revzina (red.) Aktual'nye problemy russkoj morfologii. Moskva: MGU, 1988, 66-79.]

Скоробогатова, Елена А. Грамматические значения и поэтические смыслы: поэтика именных категорий в текстах и идиостилях. Харьков: Харьковское историко-филологическое общество, 2014.

[Skorobogatova, Elena A. Grammaticheskie znacheniya i poeticheskie smysly: poetika imennyh kategorij v tekstah i idiostilyah. Har'kov: Har'kovskoe istoriko-filologicheskoe obshchestvo, 2014.]

Скоробогатова, Елена А. Грамматические значения и поэтические смыслы: поэтический потенциал русской грамматики (морфологические категории и лексико-грамматические разряды имени). Харьков: НТМТ, 2012.

[Skorobogatova, Elena A. Grammaticheskie znacheniya i poeticheskie smysly: poeticheskij potencial russkoj grammatiki (morfologicheskie kategorii i leksiko-grammaticheskie razryady imeni). Har'kov: NTMT, 2012.]

Скоробогатова, Олена. О. Поетичний потенціал іменних граматичних категорій (на матеріалі російської поезії XIX-XXI століть): дис. ... доктора філол. наук. Київ, 2015. 
[Skorobogatova, Olena. O. Poetichnij potencial imennih gramatichnih kategorij (na materiali rosijs'koï poeziï XIX-XXI stolit'): dis. ... doktora filol. nauk. Kiïv, 2015.]

Тарасова, Ирина А. ««Каждый бы подумал, как подумал Пушкин»: когнитивные механизмы интертекстуальности». [В:] Художественный текст как динамическая система. Материалы международной научной конференции, посвященной 80-летию В. П. Григорьева / Институт русского языка им. В. В. Виноградова РАН/ (Москва, 19-22 мая 2005 г.). Москва: «Управление технологиями, 2006, 95-103.

[Tarasova, Irina A. ««Kazhdyj by podumal, kak podumal Pushkin»: kognitivnye mekhanizmy intertekstual'nosti». [V:] Hudozhestvennyj tekst kak dinamicheskaya sistema. Materialy mezhdunarodnoj nauchnoj konferencii, posvyashchennoj 80 letiyu V.P. Grigor'eva / Institut russkogo yazyka im. V.V. Vinogradova PAH/ (Moskva, 1922 maya 2005 g.). Moskva: «Upravlenie tekhnologiyami, 2006, 95-103.]

Тильман, Юлия Д. «Пространство в языковой картине мира Ф. И. Тютчева (концепт круг)». [В:] Н. Д. Арутюнова, И. Б. Левонтина (отв.ред.) Логический анализ языка. Языки пространств. Москва: Языки русской культуры, 2000, 440-448.

[Til'man, Yuliya D. «Prostranstvo v yazykovoj kartine mira F.I. Tyutcheva (koncept krug)». [V:] N.D. Arutyunova, I.B. Levontina (otv.red.) Logicheskij analiz yazyka. Yazyki prostranstv. Moskva: Yazyki russkoj kul'tury, 2000, 440-448.]

Тынянов, Юрий Н. Проблема стихотворного языка. Статьи. Москва: Советский писатель, 1965.

[Tynyanov, Yurij N. Problema stihotvornogo yazyka. Stat'i. Moskva: Sovetskij pisatel', 1965.]

Хамитов, Назип. Философия одиночества. Киев: «Наукова думка», 1995. $<$ http://royallib.com/book/hamitov_nazip/filosofiya_odinochestva.html> 15.03.2021.

[Hamitov, Nazip. Filosofiya odinochestva. Kiev: «Naukova dumka», 1995. < http://royallib.com/book/hamitov_nazip/filosofiya_odinochestva.html> 15.03.2021.]

Шелякин, Михаил А. Функциональная грамматика русского языка. Москва: Русский язык, 2001.

[Shelyakin, Mihail A. Funkcional'naya grammatika russkogo yazyka. Moskva: Russkij yazyk, 2001.]

Эпштейн, Михаил Н. Стихи и стихия. Природа в русской поэзии, XVIII-XX в.в. (серия «Радуга мысли»). Самара: Издательский дом «БАХРАХ-М», 2007.

[Epshtejn, Mihail N. Stihi i stihiya. Priroda v russkoj poezii, XVIII-XX v.v. (seriya «Raduga mysli»). Samara: Izdatel'skij dom «BAHRAH M», 2007.]

Яковлева, Елена С. «Пространство умозрения и его отражение в русском языке». [В:] Н. Д. Арутюнова, И. Б. Левонтина (отв.ред.) Логический анализ языка. Языки пространств. Москва: Языки русской культуры, 2000, 268-276.

[Yakovleva, Elena S. «Prostranstvo umozreniya i ego otrazhenie v russkom yazyke». [V:] N.D. Arutyunova, I.B. Levontina (otv.red.) Logicheskij analiz yazyka. Yazyki prostranstv. Moskva: Yazyki russkoj kul'tury, 2000, 268-276.]

Samsonenko, Nataliia. "Grammatical representation of motive of meditative and contemplative loneliness (a case study of the Russian-language poetry of the XIXth-XXIst centuries)». Лігвістичні студї: збірник наукових праць 34, 2017: 138-142.

[Samsonenko, Nataliia. «Grammatical representation of motive of meditative and contemplative loneliness (a case study of the Russian-language poetry of the XIXth-XXIst centuries)». Ligvistichni studiii: zbirnik naukovih prac' 34, 2017: 138 -142.]

\section{Використані джерела}

Андриасов, Аташ. Островное бытие. Ростов на Дону, 2013.

[Andriasov, Atash. Ostrovnoe by`tie. Rostov na Donu, 2013.] 
Блок, Александр А. Собрание сочинений в восьми томах. Москва-Ленинград: «Государственное издательство художественной $\quad$ литературы». $1960 . \quad$ T. 1. Стихотворения (1897-1904).

[Blok, Aleksandr A. Sobranie sochinenij v vos`mi tomax. Moskva-Leningrad: «Gosudarstvennoe izdatel`stvo xudozhestvennoj literatury`». 1960. Т. 1. Stixotvoreniya (1897 1904).]

Глазков, Нколай И. Избранное. Москва: Худож. лит., 1989.

[Glazkov, Nkolaj I. Izbrannoe. Moskva: Xudozh. lit., 1989.]

Дементьев, Андрей Д. Стихотворения. 5-е изд. Москва: Эксмо, 2010.

[Dement`ev, Andrej D. Stixotvoreniya. 5-e izd. Moskva: E`ksmo, 2010.]

Иванов, Георгий В. Что-то сбудется. Москва: Эксмо, 2011.

[Ivanov, Georgiy. Chto-to Sbudetsya. Moskva.: Eksmo, 2011]

Кенжеев, Бахыт. Стихотворения. Москва: АО Издательство «ПАN», 1995.

[Kenzheev, Bahyt. Stihotvoreniya. Moskva: AO Izdatel'stvo «PAN», 1995.]

Кузнецов, Юрий П. Стихотворения. Москва: Эксмо, 2011.

[Kuznetsov, Yuriy. Stikhotvoreniya. Moskva: Eksmo, 2011.]

Мандельштам, Осип Э. Полное собрание стихотворений. СПб.: Гуманитарное агенство «Академический проект», 1997.

[Mandel'shtam, Osip E. Polnoe sobranie stihotvorenij. SPb.: Gumanitarnoe agenstvo «Akademicheskij proekt», 1997.]

Некрасов, Николай А. Стихотворения. Москва: Худож. лит., 1985.

[Nekrasov, Nikolaj A. Stihotvoreniya. Moskva: Hudozh. lit., 1985.]

Огарёв, Николай П. Стихотворения и поэмы. Большая серия. Второе издание. Ленинград: Сов. писатель, 1956.

[Ogarev, Nikolay. Stikhotvoreniya i Poemy. Leningrad: Sov. Pisatel', 1956.]

Павлова, Вера. Ручная кладь. Стихи 2004-2005 г.г. Москва: Захаров, 2007.

[Pavlova, Vera. Ruchnaya klad'. Stihi 2004-2005 g.g. Moskva: Zaharov, 2007.]

Полозкова, Вера. Непоэмание. < http://modernpoetry.ru/contemporary/vera-polozkovanepoemanie> 17.03.2021.

[Polozkova, Vera. Nepoemanie. <http://modernpoetry.ru/contemporary/vera-polozkova-nepoemanie.> 17 March. 2021.]

Рахлина, Марлена. Потерявшиеся стихи: Книга стихов. Харьков: Фолио, 1996.

[Rakhlina, Marina. Poteryavshiyesya Stikhi: Kniga Stikhov. Khar'kov: Folio, 1996.]

Рахлина, Марлена. Прозрачные слова. Харьков: Права людини. 2006.

[Rahlina, Marlena. Prozrachnye slova. Har'kov: Prava lyudini. 2006.]

Ходасевич, Владимир Ф. Стихотворения. Москва: «Звонница-МГ», 2003.

[Hodasevich, Vladimir F. Stihotvoreniya. Moskva: «Zvonnica-MG», 2003.]

Шаламов, Варлам Т. Колымские тетради. Москва: Эксмо, 2011.

[Shalamov, Varlam T. Kolymskie tetradi. Moskva: Eksmo, 2011.]

\section{NUMBER CATEGORY ACTUALIZATION AND THE ROLE OF MORPHOLOGICAL DOMINANT OF NUMBER WITHIN THE TEXT STRUCTURE IN RUSSIAN-LANGUAGE POETRY OF NEW TIME Nataliia Samsonenko \\ Department of Pedagogy, Foreign Philology and Translation, Simon Kuznets Kharkiv National University of Economics, Kharkiv, Ukraine}

\section{$\underline{\text { Abstract }}$}

Background: The lyrical work structure is a complex formation of different language levels units, which form a text unity due to their close interaction and complex organization. We consider grammatical means that perform both sense forming and expressive function in the poetic text to be important in the complex of different language levels means that create the compositional structure of the lyrical work. The actuality of the study of morphological units poetic functioning and the in- 
vestigation of the expressive potential of normative grammatical forms usage in the piece of poetry is determined by general anthropocentric orientation of philological researches and predetermined by the tasks of modern linguopoetics. The problem of the functioning of the same type morphological forms within a particular text space or its fragment, the concentraton of which leads to the formation of the morphological dominant of the poetic text, still remains insufficiently studied nowadays. An advanced direction of modern linguopoetics is the one that considers the phenomenon of the morphological dominant and it's role in the compositional structure of the lyrical work.

Purpose: The purpose of this paper is to describe the role of morphological dominant of the number category within the structure of the poetic text or its fragment, i.e. to investigate the role of concentration of the same type grammatical forms and meanings in the poetic text- and sense formation due to the number category actualization.

Results: The study allowed to identify and describe the features of the inerralation between the morphological structure of the lyrical work and its compositional structure. Author's selection and concentration of the same type grammatical forms and meanings within the poetic text or its fragment lead to the formation of a morphological dominant. The presence of the morphological dominant significantly increases the expressiveness of the poetic text and, as a rule, is associated with the formation and transmission of a certain poetic meaning.

Actualization of number category forms and meanings causes poetic expressiveness of this category within the morphological dominant of number. The concetration of the singular grammems in the lyrical work leads to the formation of a singular dominant. Singular dominants convey the meaning of loneliness and at the grammatical level actualize this meaning in the poetic text. The singular representation of the motive of loneliness has different variants of realization, but the author's grammatical selection, conscious or subconscious, is one of the means of actualization of the poetic meaning. The main motive of texts with a singular dominant, the motive of loneliness, is divided into meditative and contemplative loneliness, loneliness among people, love loneliness, loneliness of the poet, motive of poetic creativity, motive of sadness, separation, motive of way, motive of memorie / pity for the past, the motive expressing the feeling of a life partner necessity as opposed to loneliness, the motive of death inevitability, a certain life scenario, the motive of dying, withering, the motive of devotion and monogamy. The list of motives that are actualized by the concentration of the singular grammems which form a singular morphological dominant is open.

The concentration of plural grammems lead to the formation of a plural dominant, which we refer to as an actualized type of dominant. In the poetic text the plural dominant promotes actualization of the following meanings:plural uniformity, continuity, cyclicity of the occurring processes, cyclicity of processes development to emphasize the uniqueness and singularity of the event or the described phenomenon, when using single singular grammems among plural. The plural morphological dominant can also actualize the meaning of space and its length.

Discussion: The concentration of the same type morphological forms within the piece of poetry is based on the author's selection and leads to the formation of the morphological dominant which is related to the content of the lyrical text. Morphological units and categories within the morphological dominant acquire the features of poetic functioning, obeying the laws of the national language and the language of poetry. Actualization of stable grammatical meanings in the language and the formation of contextual meanings of morphological units in the poetic text creates expressive effects, becomes the basis for the formation and transmission of special poetic motives and meanings, increases the ambiguity of the lyrical work. The concentration of the same type number forms and meanings in the Russian-language poetic text or its fragment leads to the formation of morphological dominant of the number category. This technique is one of the means of additional expressive effects creation and special motives transmission in the piece of poetry.

The prospect of the further research implies the study of various types of verbal and nominal morphological dominants of the poetic text and the investigation of their role in the structure of the lyrical work. 
Key words: morphological dominant, singular dominant, plural dominant, number category, selection, condensation of morphological form, motive, poetic text.

Vitae

Nataliia Samsonenko is a Candidate of Philological Sciences, Assocate Professor, Associate Professor of the Department of Pedagogy, Foreign Philology and Translation of Simon Kuznets Kharkiv National University of Economics. Her areas of research interests comprise poetic grammar and linguopoetics.

Correspondence: samsonenko.nataliia@gmail.com

Надійшла до редакції 22 березня 2021 року Рекомендована до друку 5 квітня 2021 року 